\title{
INVESTIGATION OF THE USE OF E-TICKETING IN PUBLIC TRANSPORT BY THE STUDENTS OF THE ARISTOTLE UNIVERSITY OF THESSALONIKI, GREECE
}

\author{
S. BASBAS ${ }^{1}$, M.O. SKANDAMI ${ }^{1}$, G. MINTSIS ${ }^{1}$, C. TAXILTARIS ${ }^{1} \&$ I. POLITIS ${ }^{2}$ \\ ${ }^{1}$ Faculty of Rural \& Surveying Engineering, Aristotle University of Thessaloniki, Greece. \\ ${ }^{2}$ Faculty of Civil Engineering, Aristotle University of Thessaloniki, Greece.
}

\begin{abstract}
This article examines a specific aspect of e-payment: e-ticketing in public transport. The reference area is the campus of the Aristotle University of Thessaloniki, which is the largest university in Greece with more than 73,000 students. The target group was the students of the university campus. The methodology used included a stated preference survey which took place in May 2015. During the survey 300 questionnaires were collected and analysed using descriptive and inferential statistics. In addition, a binary logistics model was developed, analysing the intention of the students to use the e-ticketing system, which is under examination for the city of Thessaloniki. From the analysis, it was found that more than $86.7 \%$ of the students would be willing to use e-ticketing in public transport. They consider time saving as the most important reason for someone to use e-ticketing. An interesting finding is that $64.2 \%$ of the students would like to use their smart cards or cell phones not just for e-ticketing but also for other applications. The binary logistics model has pointed out that age, gender, car availability and familiarity with e-booking are statistically important factors for the students' intention to use the e-ticketing system.

Keywords: binary regression, descriptive and inferential analysis, electronic ticketing, public transport, university students.
\end{abstract}

\section{INTRODUCTION}

Intelligent transport systems play an important role in the daily operation of public transport systems worldwide. For example, smart ticketing is now considered a requirement by many travellers [1]. One of the most important benefits from the introduction of smart card ticketing in a public transport system has to do with time savings for the passengers. According to a research concerning the public transportation system of Trondheim, there is an estimated time saving of $6.8 \mathrm{~s}$ for each boarding passenger using a smart card [2]. Data concern students at the Norwegian University of Science and Technology, during the spring of 2009, but these time savings may be underestimated [2]. It is worthwhile to mention at this point that $75 \%$ of the public transport smart card users in the city of Rotterdam stated that they were satisfied; at the same time incidental passengers and youth have more positive opinions [3].

A research by the Department for Transport suggests that there could be a net annual benefit of over $£ 1$ billion per year to public transport stakeholders (passengers, operators and local authorities) from the roll-out of smart and integrated ticketing across England [4]. Another objective of an integrated e-ticketing scheme is to change the modal shift in favour of public transport although it is not clear if this measure alone is enough to achieve this objective [5].

This paper is part of the proceedings of the 22nd International Conference on Urban Transport and the Environment (Urban Transport 2016)

www.witconferences.com 
Results in the case of London, where the e-ticketing system 'Oyster' was introduced in 2003, show that public transport share grew from $34 \%$ in 2000 to $41 \%$ in 2009 [5].

The use of customers' mobile devices is an innovative ticketing solution; such a system was recently tested within the framework of a project in the city of Porto [6]. Athens Urban Transport Organization S.A. has had a mobile ticketing application for its customers, named 'TfA tickets' since December 2014 [7].

Issues concerning effectiveness and security affect the use of e-ticketing. The upgrading of the e-ticketing system in the city of Brescia resulted in the distribution of 1,250 cards to public transport users in April 2012. As far as the reliability of the new system is concerned, less than $2 \%$ of all the cards that had been used were defective [8]. Despite the fact that e-ticketing services can be used for different services, they must fulfil some common requirements like authenticity, non-repudiation, integrity and state [9]. Finally, although the diffusion of new technologies is very fast it must be noticed that 'the expected termination of the traditional fare product concept with the introduction of contactless smart cards has not been matched by the reality' [10].

Within the framework of this study, the intention of university students to use e-ticketing systems in public transport is examined. The article analyses the factors that are associated with the students' willingness to replace the conventional payment with an electronic one.

\section{UNDERTAKEN RESEARCH}

In order to investigate the use of electronic ticketing by the students of the Aristotle University of Thessaloniki (AUTH), a questionnaire survey was designed and addressed to the students of the AUTH [11]. The survey took place in May 2015 before the final exams of the semester. The questionnaire is divided into three sections. The first section concerns the socio-economic characteristics of the students, such as age, gender, area of residence, their faculty/school. The area of residence was defined based on intersections and/or points of



Figure 1: Students' residential area zones. 
interest, located nearby the resident of the responders. After the investigation was completed, the residential area was re-coded into three zones (zone $1:<1 \mathrm{~km}$, zone $2: 1-5 \mathrm{~km}$, zone 3 : $>5 \mathrm{~km}$ ) with the AUTH as the central point, as shown in Fig. 1. The second section examines the mobility profiles (characteristics) of the students, for the trip home - AUTH. The last section deals with questions about e-ticketing, such as whether or not the students have had previous experience with e-ticketing, whether or not they are going to use it when it would be implemented in Thessaloniki and why.

\subsection{Descriptive statistics}

Table 1 presents the descriptive statistics of the variables that were examined in this study. As the table shows, almost equal representativeness was achieved between the genders since the sample consists of $46 \%$ men and 54\% women. The majority of the responders (94.8\%) were aged less than 24 years since the survey concerned university students. The remaining $5.2 \%$, aged over 24 years, probably were students who had postponed their graduation for several

Table 1: Coding, measurement scale and frequency statistics of the variables.

\begin{tabular}{|c|c|c|c|}
\hline Code & Explanation & Values & Frequency $(\%)$ \\
\hline GENDER & Gender & 0: Male, 1: Female & $0: 44.0,1: 56.0$ \\
\hline AGE & Age & Original responses & 18-24: $94.8,>24: 5.2$ \\
\hline $\begin{array}{l}\text { MONTH_ } \\
\text { INC }\end{array}$ & $\begin{array}{l}\text { Private monthly } \\
\text { income }\end{array}$ & $\begin{array}{l}\text { 1: } 0-800,2: 801-1,600,3: \\
\text { 1,601-2,400, 4: >2,400, 5: } \\
\text { Don't know, 6: Don't want } \\
\text { to answer this question }\end{array}$ & $\begin{array}{l}1: 82.0,2: 5.7,3: 1.0, \\
4: 0.0,5: 7.0, \\
6: 4.3\end{array}$ \\
\hline ZONE & Area of Residence & $1: 0-1,2: 1-5,3:>5(\mathrm{~km})$ & $\begin{array}{l}\text { 1: } 21.7,2: 56.3,3: \\
\text { 21.7, Missing } \\
\text { values: } 0.3\end{array}$ \\
\hline Car_Avail & Car availability & $0:$ Yes, 1: No & $0: 71.0,1: 29.0$ \\
\hline $\begin{array}{l}\text { MAIN_- } \\
\text { USER }\end{array}$ & Main user & $0:$ Yes, 1: No & $0: 17.2,1: 82.8$ \\
\hline MEANS & $\begin{array}{l}\text { Transport mean to } \\
\text { and from AUTH }\end{array}$ & $\begin{array}{l}\text { 1: car(driver), } 2: \\
\text { car(passenger), } \\
\text { 3: bus, 4: motorcycle, } \\
\text { 5: bicycle, 6: pedestrian }\end{array}$ & $\begin{array}{l}1: 8.0,2: 1.0 \\
3: 58.7,4: 2.3 \\
5: 2.0,6: 28.0\end{array}$ \\
\hline $\begin{array}{l}\text { TIMES } \\
\text { DAY }\end{array}$ & $\begin{array}{l}\text { Frequency of trans- } \\
\text { portation }\end{array}$ & Original responses & $\begin{array}{l}0-1: 70.7,2-3: 27.7 \\
\text { Missing values: } 1.0\end{array}$ \\
\hline $\begin{array}{l}\text { BUS__ }_{-} \\
\text {TICKET }\end{array}$ & Bus ticket & $\begin{array}{l}\text { 1: 1-route ticket, 2: 2-routes } \\
\text { ticket, 3: 3-routes ticket, } \\
\text { 4: 4-routes ticket, } \\
\text { 5: unlimited travel cards, } \\
\text { 6: I do not use ticket }\end{array}$ & $\begin{array}{l}\text { 1: } 44.7,2: 6.7 \\
\text { 3: } 0.0,4: 0.3, \\
\text { 5: 42.0, } 6: 2.7 \\
\text { Missing values: } 3.7\end{array}$ \\
\hline
\end{tabular}


Table 1: (Continued).

\begin{tabular}{|c|c|c|c|}
\hline Code & Explanation & Values & Frequency (\%) \\
\hline $\begin{array}{l}\text { e-banking } \\
\text { e-commerce } \\
\text { e-booking }\end{array}$ & $\begin{array}{l}\text { Familiarity with } \\
\text { 1. e-banking } \\
\text { 2. e-commerce } \\
\text { 3. e-booking }\end{array}$ & $\begin{array}{l}\text { 1. } 0: \text { Yes, } 1: \text { No } \\
\text { 2. } 0: \text { Yes, } 1: \text { No } \\
\text { 3. 0: Yes, } 1: \text { No }\end{array}$ & $\begin{array}{l}\text { 1. } 0: 43.0,1: 57.0 \\
\text { 2. } 0: 26.2,1: 73.8 \\
\text { 3. } 0: 53.7,1: 46.3\end{array}$ \\
\hline $\begin{array}{l}\text { PREVIOUS_ } \\
\text { EXP }\end{array}$ & $\begin{array}{l}\text { Previous experience } \\
\text { with e-ticketing }\end{array}$ & 0: Yes, 1: No & $0: 35.8,1: 64.2$ \\
\hline E_USE & $\begin{array}{l}\text { I will use e- } \\
\text { ticketing }\end{array}$ & $0:$ Yes, 1: No & $0: 86.7,1: 13.3$ \\
\hline $\begin{array}{l}\text { TIME_ } \\
\text { BENEFIT }\end{array}$ & Time benefit & $\begin{array}{l}\text { 1: Very important } \\
\text { 2: Important } \\
\text { 3: Least important }\end{array}$ & $\begin{array}{l}1: 48.6 \\
2: 43.2 \\
3: 8.2\end{array}$ \\
\hline EASY_USE & Ease of use & $\begin{array}{l}\text { 1: Very important } \\
\text { 2: Important } \\
\text { 3: Least important }\end{array}$ & $\begin{array}{l}1: 46.7 \\
2: 45.1 \\
3: 8.2\end{array}$ \\
\hline $\begin{array}{l}\text { MONEY_- } \\
\text { BENEFIT }\end{array}$ & Money benefit & $\begin{array}{l}\text { 1: Very important } \\
\text { 2: Important } \\
\text { 3: Least important }\end{array}$ & $\begin{array}{l}1: 44.9 \\
2: 41.8 \\
3: 13.3\end{array}$ \\
\hline $\begin{array}{l}\text { EXTRA_- } \\
\text { MVMNTS }\end{array}$ & Additional trips & $0:$ Yes, 1: No & $0: 64.2,1: 35.8$ \\
\hline $\begin{array}{l}\mathrm{HOW}_{-} \\
\mathrm{MANY}\end{array}$ & How many & $1: 2,2: 4,3:>4$ & $\begin{array}{l}1: 44.2,2: 11.5, \\
3: 44.3\end{array}$ \\
\hline $\begin{array}{l}\text { OTHER_ } \\
\text { USES }\end{array}$ & Additional uses & $0:$ Yes, 1: No & $0: 64.2,1: 35.8$ \\
\hline WHICH & Which uses & $\begin{array}{l}\text { 1: Transportation, 2: Shop- } \\
\text { ping, 3: Tourism. 4: Culture } \\
\text { 5: Private and public ser- } \\
\text { vices 6: Medical care, } \\
\text { 7: Other }\end{array}$ & $\begin{array}{l}1: 29.0,2: 31.9 \\
3: 18.8,4: 15.2, \\
5: 2.2,6: 0.0,7: 2.9\end{array}$ \\
\hline
\end{tabular}

reasons or postgraduate students. As mentioned above, the area of residence was split into three zones, with more than $50 \%$ of the surveyed students living in Zone 2.

The most common transport means that the students use for their transportation to and from the campus is the bus $(58.7 \%)$ while only $26 \%$ prefer walking. This finding is consistent with findings from a previous study conducted in the AUTH in 2011 [12]. The passengers are likely to use either single route tickets $(44 \%)$ or travel cards $(42 \%)$ for a specific period (e.g. monthly cards) for their trip. It is has been found that more than half of the students are not familiar with e-banking (47\%) and e-commerce (73.8\%), while 53\% stated that were familiar with e-booking.

Although there seems to be a relatively small percentage $(35.8 \%)$ of students with previous experience of e-ticketing, it has been found that $86.7 \%$ of the respondents will use the 
e-ticketing system when it is implemented in Thessaloniki. Finally, as shown in Table 1, $48.6 \%$ of those who will use the system consider time benefits as very important, $46.7 \%$ believe that it will be easy to use it and $44.9 \%$ believe that they will benefit in monetary terms.

\subsection{Inferential statistics}

This section presents the most important inferential statistical tests that were carried out within the framework of the study. The first correlation refers to the nominal variables of 'gender' and that variable asking about the additional use of the e-ticket (variable coded as 'WHICH'). Figure 2 presents the differences among the genders. The inferential test that was performed was a chi-square test, $\chi^{2}(5, N=138)=11.385, p<0.05$.

Figure 3 presents the inferential test between the variables 'area of residence' and 'transportation means to and from the AUTH'. The chi-square test confirmed a statistically significant difference $\chi^{2}(10, N=299)=93.969, p<0.001$. As shown in Fig. 3, the students who live in Zone 2 (1-5 km from the AUTH) use the bus mainly for their trips while the students who live in Zone 1 mainly prefer to come to the university on foot.

Figure 4 presents the variable 'area of residence' in relation to the 'bus ticket type' that is used. The chi-square test also confirmed a statistically significant difference, $\chi^{2}(8, N=288)=$ $50.133, p<0.001$. As expected, students living in Zone 1 (distance less than $1 \mathrm{~km}$ ) use mainly the simple ticket, while students living in Zones 2 and 3 use both simple tickets and unlimited travel cards.

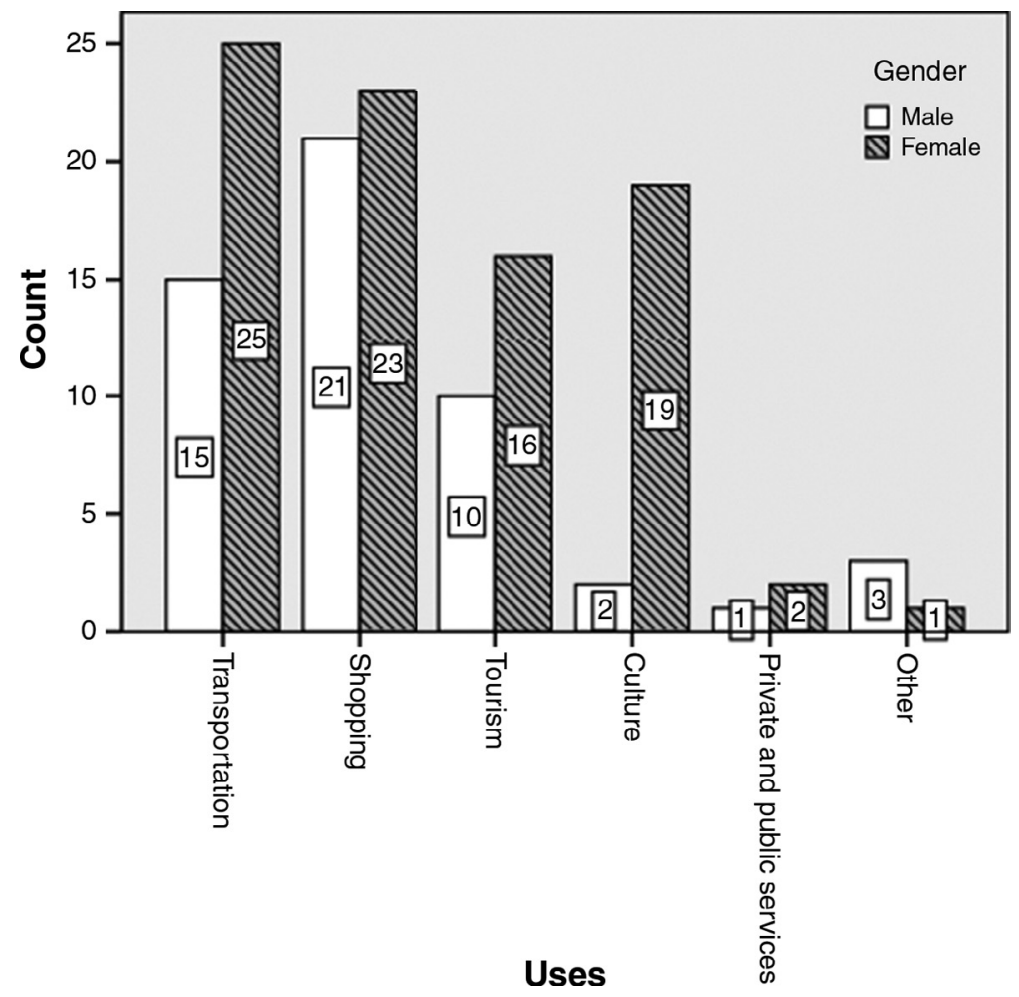

Figure 2: Additional uses relative to gender. 


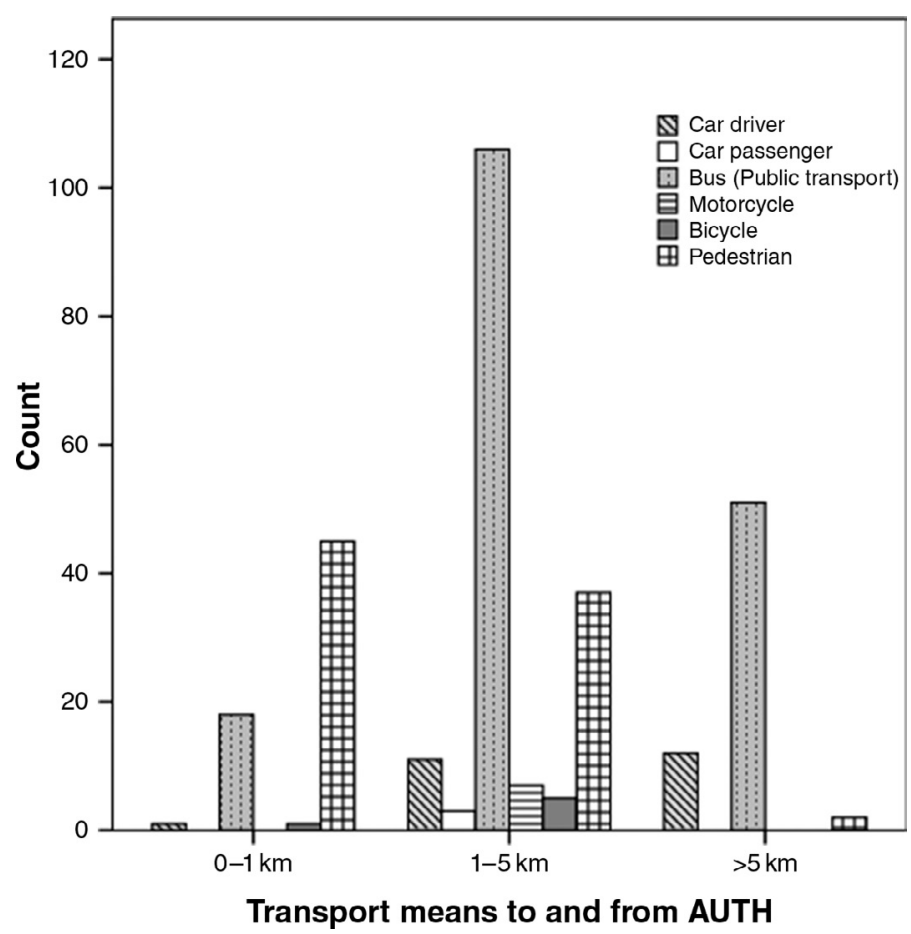

Figure 3: Transport means to and from the AUTH relative to area of residence.

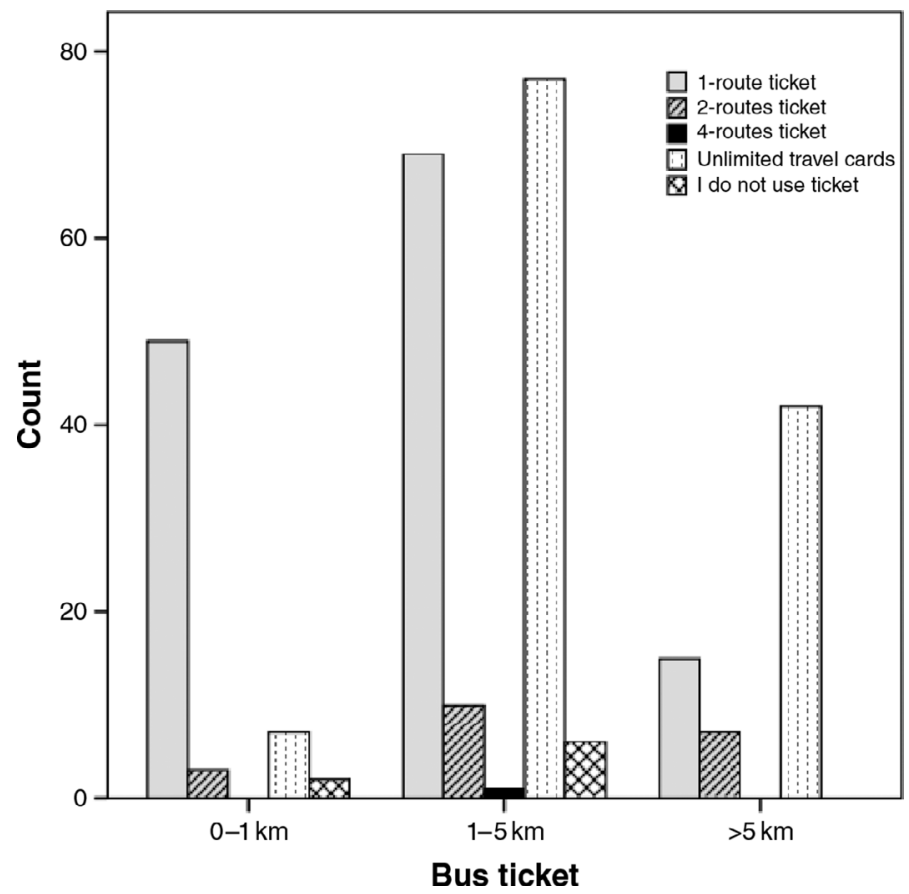

Figure 4: Bus ticket type relative to area of residence. 


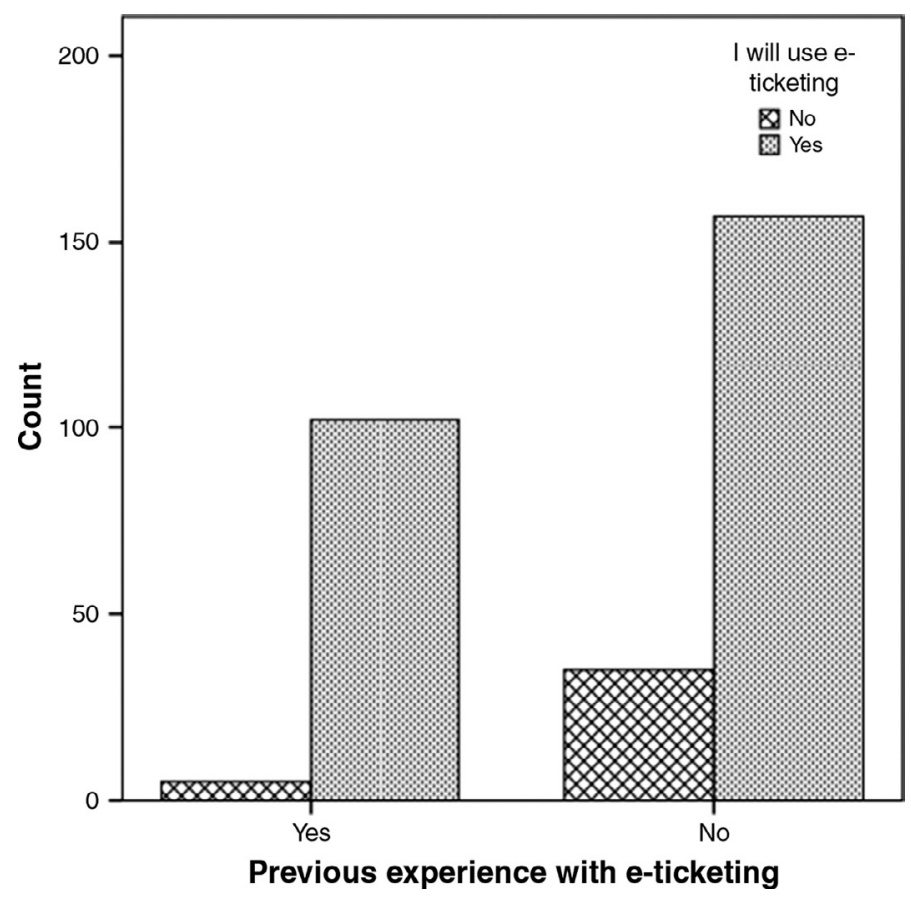

Figure 5: Previous experience with e-ticketing relative to preferred use of e-ticketing.

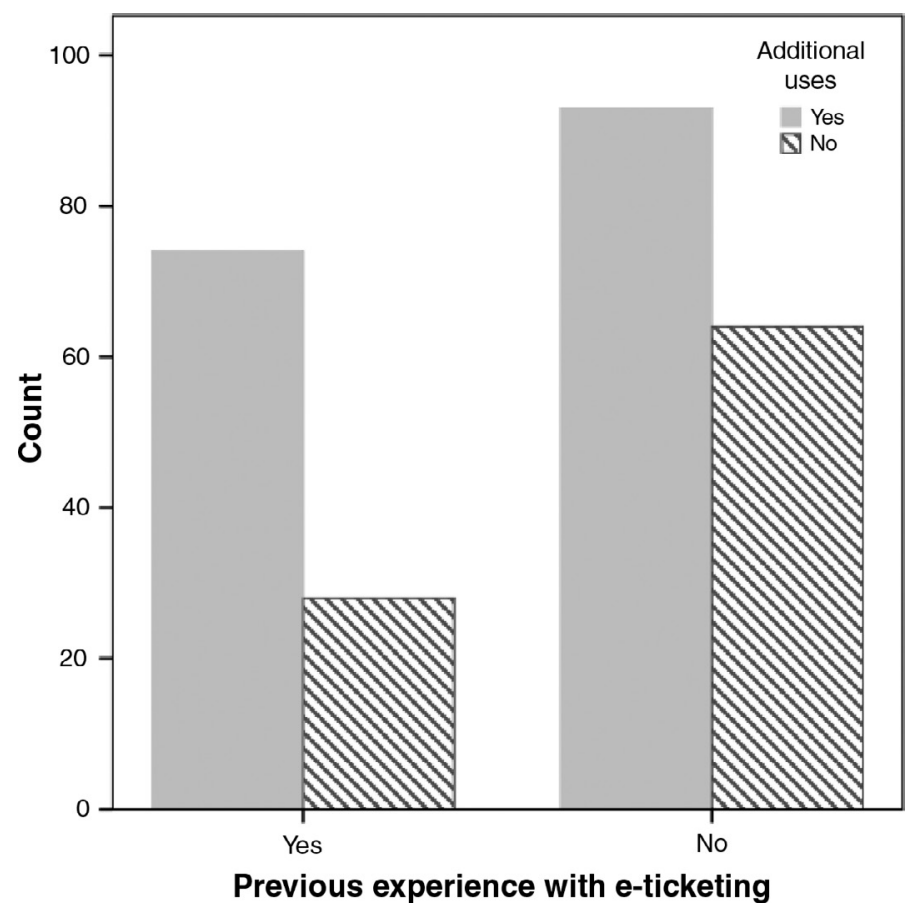

Figure 6: Previous experience with e-ticketing relative to other uses of the card. 


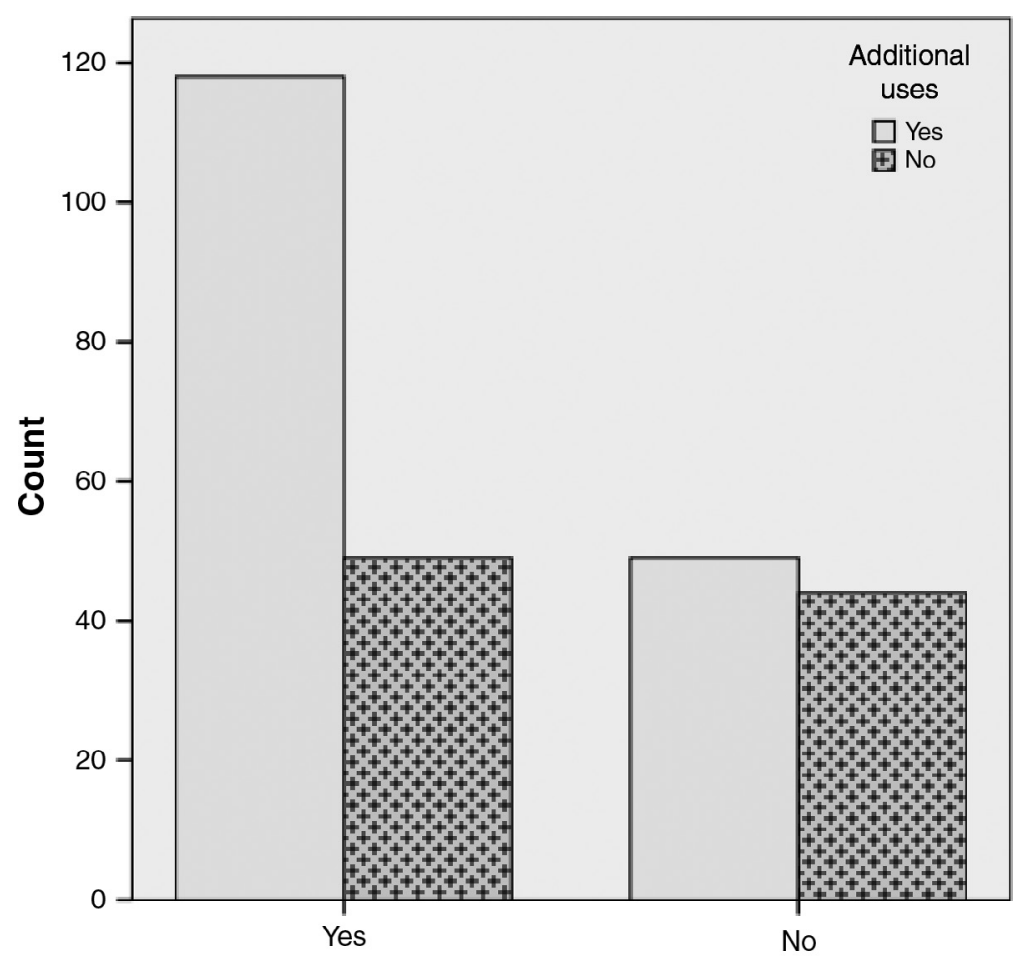

Additional Trips by Public Transport

Figure 7: Additional trips relative to additional uses.

Figures 5 and 6 present the relation between the participants' familiarity with e-ticketing and their intention to use the examined system as well as their intention to make additional trips. Both inferential tests show a statistically significant difference between the variables. Figure 5 reveals that students with limited experience in e-ticketing systems are not warm supporters of the examined system. Figure 6 shows that students with limited experience in e-ticketing systems have stated that they will not use it as an integrated smart card for other purposes such as shopping, banking and booking.

Finally, Fig. 7 presents the relation of the integrated role of the smart card and the students' intention to make additional trips (by bus). In this figure it is shown that students who are negative towards the use of the bus ticket for additional electronic purposes have strongly stated that they will not be willing to make any additional trips.

\section{THE BINARY LOGISTICS REGRESSION MODEL}

In order to investigate whether the students of the university will use the e-ticketing system, a binary logistics regression model was developed. The purpose was to identify the odds ratio of the independent variables related with the dependant variable 'I will use the e-ticket'.

\subsection{The binary logistics regression model}

Binary logistics models are used to predic a categorical (dichotomous) variable from a set of predictor variables. The prediction is actually measured as the possibility of an event to take place, compared to the possibility for the event not to take place. In binary logistics models, 
the dependent variable concerns the logarithm of the odds ratio and therefore the mathematical expression as a generalized linear model can be written as follows:

$$
\ln \frac{p_{i}}{1-p_{i}}=\beta_{0}+\beta_{1} \mathrm{X}_{1, i}+\beta_{2} \mathrm{X}_{2, i}+\cdots+\beta_{N} \mathrm{X}_{n, \mathrm{i}}
$$

In terms of odds, the model above can be written as follows:

$$
\frac{p_{i}}{1-p_{i}}=e^{\left(\beta_{0}+\beta_{1} \mathrm{X}_{1, i}+\beta_{2} \mathrm{X}_{2, i}+\cdots+\beta_{N} \mathrm{X}_{n, \mathrm{i}}\right)}
$$

In terms of the probability of occurrence of the outcome, it may be written as follows:

$$
p_{i}=\frac{e^{\left(\beta_{0}+\beta_{1} \mathrm{X}_{1, i}+\beta_{2} \mathrm{X}_{2, i}+\cdots+\beta_{N} \mathrm{X}_{n, \mathrm{i}}\right)}}{1+e^{\left(\beta_{0}+\beta_{1} \mathrm{X}_{1, i}+\beta_{2} \mathrm{X}_{2, i}+\cdots+\beta_{N} \mathrm{X}_{n, \mathrm{i}}\right)}}
$$

In the binary logistics model of this study, the possibility of the students to use or not use the e-ticket system is estimated. Table 2 presents the results of the overall fitting statistical test, the Hosmer and Lemeshow test and the R square tests of Cox and Snell and Nagelkerke. The non-rejection of the null hypothesis of the Hosmer-Lemeshow test indicates that there is linear relationship between the predictor variables and the log odds of the criterion variable. The outcome therefore is that the data are fitting the model well and there is not any specification error in the model.

Table 3 presents the parameter (beta) estimates of the binary logistics regression model of the study, the standard error (SE), the Wald statistic, the significance level as well as the exponential of the beta estimates.

From Table 3 it can be easily concluded that the majority of the variables presented in the previous sections do not seem to have any statistical intepretation power to predict whether or not the students will use the e-ticket.

The predictors that were found to have statistical power on dependent variable differentiation are age, gender, experience in e-booking and car availability. An explanation of how these four variables affect the possibility of using or not using the e-ticketing system is presented in the following paragraphs through the calculation of odds, probabilities of odds and the odds ratio values. (Detailed calculations, however, are not presented in this article.)

- Regarding car availability: From the conversion of the odds to probabilities, it is estimated that $50 \%$ of the students who have stated that they are owners of a car are positive towards

Table 2: Overal fitting indices for the binary logistics regression model.

\begin{tabular}{ccc}
\hline Model summary & & \\
\hline-2 log likelihood & Cox and Snell R Square & Nagelkerke R Square \\
203.256 & 0.492 & 0.657 \\
\hline Hosmer and Lemeshow Test & & Sig. \\
\hline Chi-square & df & 0.685 \\
\hline
\end{tabular}


Table 3: Parameter estimates for the binary logistics regression.

\begin{tabular}{lcccccc}
\hline Variable code & Beta estimates & SE & Wald & df & Sig. & Exp(B) \\
\hline Car_Avail & -1.204 & 0.372 & 10.482 & 1 & 0.001 & 0.300 \\
e-booking & -1.002 & 0.375 & 7.133 & 1 & 0.008 & 0.367 \\
GENDER & 0.741 & 0.367 & 4.076 & 1 & 0.043 & 2.097 \\
AGE & 0.121 & 0.018 & 44.573 & 1 & 0.000 & 1.129 \\
\hline
\end{tabular}

the use of the e-ticketing system. The respective percentage for those without car availability was estimated to $23 \%$. From the odds ratio calculation, it can be concluded that the model predicts that the odds of use of the e-ticketing system are 0.3 times higher for those who have stated that they do not possess a car compared to those who have stated that they have car availability. In other words, it is clear from the survey that the students who have car availability for the same trip are in favour of the use of the e-ticketing system.

- Regarding gender: From the odd calculation, it has been found that $50 \%$ of males have stated that they will use the e-ticketing system. The respective percentage for females is $67 \%$. Therefore, from the odds ratio calculation, it can be concluded that the odds of using the e-ticketing system are 2.097 times higher for females than for males. In other words, the model estimates that women are much more positive towards the implementation of the e-ticket policy compared to men.

- Regarding age: From the conversion of the odds to probabilities, it has been estimated that being older by 1 year increases the possibility of using the e-ticketing system by $13 \%$.

- Regarding level of familiarity with e-booking: From the conversion of the odds to probabilities, it has been estimated that $50 \%$ of the students who stated that they are familiar with e-booking are positive towards the use of the e-ticketing system. The respective percentage for those without experience in e-booking was estimated to be $27 \%$. From the odds ratio calculation, it can be concluded that the model predicts that the odds of using the e-ticketing system are 0.367 times higher for those who have stated that they are not familiar with e-booking compared to those who have stated that they are. In other words, the findings show that the respondents characterized by familiarity with e-booking are in favour of the use of the e-ticketing system.

\section{CONCLUSIONS}

Smart card technologies are considered as an essential step for the improvement of public transport services nowadays. The revelation in telematics, carried out in the previous decades, have made these applications a low-cost and highly effective 'must' for modern public transport providers.

Students and more specifically university students are characterized by high mobility rates as well as by their high level of penetration in new technologies. Taking these facts into consideration, this article examined the intention of AUTH students to use e-ticketing in public transport.

Among other important outcomes, both qualitative and quantitative, it was found that previous experience in e-ticketing system is vital for the success of this initiative for the case of Thessaloniki. It was also found that more than $86.7 \%$ of the students would be willing to use 
e-ticketing in public transport. They consider time saving as the most important reason for using e-ticketing. An interesting finding is that $64.2 \%$ of the students would like to use their smart cards or cell phones not just for e-ticketing but also for other applications. The binary logistics model has pointed out that age, gender, car availability and familiarity with e-booking are statistically important factors for the students' intention to use the e-ticketing system.

The findings of the study provide an insight for policy makers and planners who are involved in the design, implementation and evaluation stages of such initiatives by highlighting the need for in-depth analysis through market segmentation.

\section{REFERENCES}

[1] Nelson, J.D. \& Mulley, C., The impact of the application of new technology on public transport service provision and the passenger experience: a focus on implementation in Australia. Research in Transportation Economics, 39(1), pp. 300-308, 2013. DOI: 10.1016/j.retrec.2012.06.028.

[2] Welde, M., Are smart card ticketing systems profitable? Evidence from the City of Trondheim. Journal of Public Transportation, 15(1), pp. 133-148, 2012. DOI: $10.5038 / 2375-0901.15 .1 .8$.

[3] Cheung, F., Nationwide implementation of public transport smartcard in the Netherlands. The Association for European Transport Conference, Leeuwenhorst Conference Centre, The Netherlands, 7-19 October 2007.

[4] Turner, M. \& Wilson R., Smart and integrated ticketing in the UK: piecing together the jigsaw. Computer Law \& Security Review, 26(2), pp. 170-177, 2010. DOI: 10.1016/j. clsr.2010.01.015.

[5] Puhe, M., Integrated urban e-ticketing schemes - conflicting objectives of corresponding stakeholders. Transportation Research Procedia, 4, pp. 494-504, 2014. DOI: 10.1016/j.trpro.2014.11.038.

[6] Ferreira, M.C., Nóvoa, H., Galvão Dias, T. \& Falcão e Cunha, J., A proposal for a public transport ticketing solution based on customers' mobile devices. Procedia - Social and Behavioral Sciences, 111, pp. 232-241, 2014. DOI: 10.1016/j.sbspro.2014.01.056 (accessed 1 February 2016).

[7] Athens Urban Transport Organization S.A., available at www.oasa.gr.

[8] CIVITAS MODERN project, 'MObility, Development and Energy use ReductioN', Implementing sustainable mobility, available at www.civitas-initiative.org/content/ development-and-upgrade-e-ticketing-system (accessed 1 February 2016).

[9] Mut-Puigserver, M., Payeras-Capella, M.M., Ferrer-Gomila, J.-L., Vives-Guasch, A. \& Castella-Roca, J., A survey of electronic ticketing applied to transport. Computers \& Security, 31(8), pp. 925-939, 2012. DOI: 10.1016/j.cose.2012.07.004.

[10] Mezghani, M., Study on Electronic Ticketing in Public Transport, Final Report, European Metropolitan Transport Authorities (EMTA), Paris, France, 2008.

[11] Skandami, M.O., Stated preference survey for the use of e-ticketing in Public Transport by the students of the Aristotle University of Thessaloniki. Diploma Thesis, Supervisor: Basbas, S., Faculty of Rural \& Surveying Engineering, Aristotle University of Thessaloniki, 2015.

[12] Papaioannou, E.M., Apostola, T., Politis, I. \& Basbas, S., Walking behavior of university students in Greece: a descriptive and inferential analysis. 5th International Conference on Traffic and Transport Psychology, Groningen, The Netherlands, 29-31 August 2012. 